\title{
Winter pasture and cover crops and their effects on soil and summer grain crops
}

\author{
Alvadi Antonio Balbinot Junior(1), Milton da Veiga ${ }^{(2)}$, Anibal de Moraes ${ }^{(3)}$, Adelino Pelissari( ${ }^{(3)}$, \\ Álvaro Luiz Mafra ${ }^{(4)}$ and Cristiano Dela Piccolla ${ }^{(4)}$
}

\begin{abstract}
(1)Embrapa Soja, Rodovia Carlos João Strass, Distrito da Warta, Caixa Postal 231, CEP 86001-970 Londrina, PR, Brazil. E-mail: balbinot@cnpso.embrapa.br (2)Empresa de Pesquisa Agropecuária e Extensão Rural de Santa Catarina, Caixa Postal 116, CEP 89620-000 Campos Novos, SC, Brazil. E-mail: milveiga@epagri.sc.gov.br ${ }^{(3)}$ Universidade Federal do Paraná, Caixa Postal 19.061, CEP 81531-990 Curitiba, PR, Brazil. E-mail: anibalm@ufpr.br, linopeli@hotmail.com ${ }^{(4)}$ Universidade do Estado de Santa Catarina, Caixa Postal 281, CEP 88520-000 Lages, SC, Brazil. E-mail: a2alm@cav.udesc.br, cpiccolla@bol.com.br
\end{abstract}

\begin{abstract}
The objective of this work was to evaluate the effect of winter land use on the amount of residual straw, the physical soil properties and grain yields of maize, common bean and soybean summer crops cultivated in succession. The experiment was carried out in the North Plateau of Santa Catarina state, Brazil, from May 2006 to April 2010. Five strategies of land use in winter were evaluated: intercropping with black oat + ryegrass + vetch, without grazing and nitrogen $(\mathrm{N})$ fertilization (intercropping cover); the same intercropping, with grazing and $100 \mathrm{~kg} \mathrm{ha}^{-1}$ of $\mathrm{N}$ per year topdressing (pasture with $\mathrm{N}$ ); the same intercropping, with grazing and without nitrogen fertilization (pasture without $\mathrm{N}$ ); oilseed radish, without grazing and nitrogen fertilization (oilseed radish); and natural vegetation, without grazing and nitrogen fertilization (fallow). Intercropping cover produces a greater amount of biomass in the system and, consequently, a greater accumulation of total and particulate organic carbon on the surface soil layer. However, land use in winter does not significantly affect soil physical properties related to soil compaction, nor the grain yield of maize, soybean and common bean cultivated in succession.
\end{abstract}

Index terms: compaction, cover crops, crop-livestock integration, no-tillage, organic carbon.

\section{Pastagem e coberturas de inverno e seus efeitos sobre o solo e culturas estivais}

Resumo - O objetivo deste trabalho foi avaliar o efeito de usos da terra no inverno na quantidade de palha remanescente, nas características físicas do solo e na produção de grãos das culturas estivais de milho, feijão e soja, cultivadas em sucessão. O experimento foi conduzido na região Planalto Norte de Santa Catarina, de maio de 2006 a abril de 2010. Foram avaliados cinco usos da terra no inverno: consórcio de aveia-preta + azevém + ervilhaca, sem pastejo e sem adubação nitrogenada (consórcio cobertura); o mesmo consórcio, com pastejo e $100 \mathrm{~kg} \mathrm{ha}^{-1}$ de nitrogênio (N) por ano em cobertura (pastagem com N); o mesmo consórcio, com pastejo e sem adubação nitrogenada (pastagem sem N); nabo forrageiro, sem pastejo e sem adubação nitrogenada (nabo forrageiro); e vegetação natural, sem pastejo e sem adubação nitrogenada (pousio). O consórcio cobertura proporciona maior quantidade de biomassa para o sistema e, consequentemente, maior acúmulo de carbono orgânico total e particulado na camada superficial do solo. No entanto, as formas de uso da terra no inverno não alteram significativamente as características do solo relacionadas à compactação, nem a produtividade de grãos das culturas de milho, feijão e soja, cultivadas em sucessão.

Termos para indexação: compactação, plantas de cobertura, integração lavoura-pecuária, plantio direto, carbono orgânico.

\section{Introduction}

In the cropping systems in Southern Brazil, soybean, maize and common bean are significant commercial crops cultivated during summer. However, from May to September, there is a lack of commercial crops with good technical and economical potential, mainly in small farms. This condition has been aggravated in the last years because of the decrease in the net income of winter cereals, due to the greater importation of these products, especially wheat (Brum et al., 2005). This situation stimulates the growth of winter fallow, which may increase soil erosion and weed infestation, notably when the emergence of spontaneous plants is

Pesq. agropec. bras., Brasília, v.46, n.10, p.1357-1363, out. 2011 
low in winter; moreover no income is generated in the farm during this period.

Winter cover crops are an important component in the cropping systems, since they can improve desirable soil properties (Giacomini et al., 2003). This improvement is directly related to the amount of organic material added to the soil, and the best alternative is sowing more than one species simultaneously, in a system called intercropping (Balbinot Junior et al., 2004). Cover crops can increase soil organic matter content over time due to greater biomass production (Diekow et al., 2005); however, the economic return is not immediate for farmers, since the investment can return within the subsequent crop or even in the following years.

An alternative to promote biological and economical benefits in a shorter period of time is the use of agricultural land for pasture production with direct grazing in an integrated crop-livestock system (Fontaneli et al., 2000; Spera et al., 2004; Balbinot Junior et al., 2009). In Southern Brazil, several winter species can produce high quality forage, such as black oat (Avena strigosa Schreb.), ryegrass (Lolium multiflorum Lam.) and vetch (Vicia sativa L. and Vicia villosa Roth.). The integrated crop-livestock system requires adequate management, since land use in winter with pasture under grazing can result in soil compaction and deficiency in straw when a no-tillage system is used (Nicoloso et al., 2006).

The rotational grazing, frequently used in dairy cattle production systems, is characterized by high animal mass per area in a short period of time, a condition which can promote soil compaction due to animal trampling when soil moisture is favorable to soil compaction (Nicoloso et al., 2006). Trein et al. (1991) observed an increase in soil penetration resistance, and a reduction in macroporosity and water infiltration at the layers of 0.000 to $0.075 \mathrm{~m}$.

Management practices, which promote root growth of pasture species, could reduce the mechanical effects of trampling. Pasture fertilization with nitrogen is a good strategy to increase pasture production and reduce surface soil compaction caused during grazing, since there is less trampling by cattle while feeding (Baggio et al., 2009). Pasture biomass also attenuates stress on the soil surface (Braida et al., 2006), and root growth can reduce soil compaction (Abreu et al., 2004).
The objective of this work was to evaluate the effect of winter land use on the amount of residual straw, the physical soil properties and grain yields of maize, common bean and soybean summer crops cultivated in succession.

\section{Materials and Methods}

The experiment was carried out from May 2006 to April 2010 at a field in the North Plateau of Santa Catarina State, Brazil (50'24'W, 26 $29^{\circ}$ 'S, at an altitude of $822 \mathrm{~m}$ above sea level). The region has a $\mathrm{Cfb}$ climate, according to the Köppen classification (Pandolfo et al., 2002). The soil was classified as Cambissolo Háplico (Inceptisol) (Solos do Estado de Santa Catarina, 2004), and, at the beginning of the experiment, had the following properties at the layers of $0-0.10$ and 0.10 $0.20 \mathrm{~m}$, respectively: 500 and $512 \mathrm{~g} \mathrm{~kg}^{-1}$ of clay; 442 and $446 \mathrm{~g} \mathrm{~kg}^{-1}$ of silt; 58 and $42 \mathrm{~g} \mathrm{~kg}^{-1}$ of sand; 61 and $38 \mathrm{~g} \mathrm{~kg}^{-1}$ of organic matter; water $\mathrm{pH}$ of 5.3 and 5.2; 11.4 and $4.1 \mathrm{mg} \mathrm{L}^{-1}$ of available P; 125 and $52 \mathrm{mg} \mathrm{L}^{-1}$ of exchangeable K; 8.7 and $7.5 \mathrm{cmol}_{\mathrm{c}} \mathrm{L}^{-1}$ of exchangeable $\mathrm{Ca}$; 4.9 and $3.7 \mathrm{cmol}_{\mathrm{c}} \mathrm{L}^{-1}$ of exchangeable $\mathrm{Mg}$.

Prior to the experiment, the field was in an integrated crop-livestock system with annual winter pasture of black oat and ryegrass, and crop rotation of common bean and maize in summer, for grain and silage (whole plant), respectively.

The experiment was in a randomized block design, with three replicates in plots with a total area of $64 \mathrm{~m}^{2}(8 \times 8 \mathrm{~m})$. The treatments consisted of five land use strategies in winter: intercropping of black oat + ryegrass + vetch (Vicia villosa), without grazing and nitrogen $(\mathrm{N})$ fertilization (intercropping cover); the same intercropping, with grazing and $100 \mathrm{~kg} \mathrm{ha}^{-1}$ of $\mathrm{N}$ per year (pasture with $\mathrm{N}$ ); the same intercropping, with grazing without $\mathrm{N}$ fertilization (pasture without $\mathrm{N}$ ); oilseed radish, without grazing and $\mathrm{N}$ fertilization (oilseed radish); and natural vegetation, without grazing and $\mathrm{N}$ fertilization (fallow).

The amount of seeds used for each crop in intercropping were $40 \mathrm{~kg} \mathrm{ha}^{-1}$ of black oat $+30 \mathrm{~kg} \mathrm{ha}^{-1}$ of ryegrass $+30 \mathrm{~kg} \mathrm{ha}^{-1}$ of vetch, and $20 \mathrm{~kg} \mathrm{ha}^{-1}$ of oilseed radish, which was single cropped. Winter crops sowing was performed with a direct-drilling planter, with $0.17 \mathrm{~m}$ between rows and approximately $0.04 \mathrm{~m}$ of depth. The same treatments were applied in the four years of the experiment. Nitrogen fertilization of 
the pasture with $\mathrm{N}$ treatment was topdressing, when black oat had in average two tillers, using urea as a $\mathrm{N}$-source.

The plots under grazing were divided with an electric fence. Two Holstein cows in lactation period were used in each plot to promote grazing, and were grouped to obtain similar animal mass, with cow live weight of 500 to $650 \mathrm{~kg}$. The height of the pasture was used to determine when to introduce and remove animals from pasture, with average height of $0.25-0.30 \mathrm{~m}$ and $0.10 \mathrm{~m}$, respectively, and grazing period of one to six hours.

The residual plant biomass of all treatments was desiccated from two to seven days after the last grazing in October or November, prior to the sowing of the summer crops, with $1.44 \mathrm{~kg} \mathrm{ha}^{-1}$ i.a. of glyphosate plus $1.5 \mathrm{~L} \mathrm{ha}^{-1}$ of mineral oil dissolved in water in a sufficient amount to apply nearly $200 \mathrm{~L} \mathrm{ha}^{-1}$ of solution with a manual sprayer. The following crop rotation, with respective cultivar, was used: maize Dekalb 214, common bean IPR Uirapuru, soybean Coodetec 206 and maize Pioneer 30B39, in the 2006/2007, 2007/2008, $2008 / 2009$ and $2009 / 2010$ crop seasons. The summer crops were sown 10 to 15 days after desiccation of winter crops; a direct-drilling planter equipped with a chisel device was used to drill the soil at a depth of $0.12 \mathrm{~m}$. The management practices used for the summer crops cultivation, including fertilization, and weeds, pests and disease control, were those usually recommended.

In the treatments with annual pasture in winter, forage consumption by animals was estimated in each plot and grazing period by the difference between dry biomass available before and after grazing, by cutting the pasture near the soil surface. The pasture biomass was sampled in a $0.25 \mathrm{~m}^{2}$ area, and the material was dried at $65^{\circ} \mathrm{C}$ until constant dry mass in an oven with forced ventilation. The amount of residual biomass at desiccation of winter cover crops was estimated by sampling the plant biomass in a $1.0 \mathrm{~m}^{2}$ area in each plot. The plant material was oven-dried at $65^{\circ} \mathrm{C}$ until constant dry mass, and weighed.

Soil physical analyses were performed in soil cores collected in the fourth year of the experiment in two subsamples per plot, at desiccation of the winter crops, using stainless steel rings with $0.05 \mathrm{~m}$ of height and $0.06 \mathrm{~m}$ of diameter in the layers of $0.00-0.05,0.05$ $0.10,0.10-0.15$, and $0.15-0.20 \mathrm{~m}$. In these samples, bulk density and macro and microporosity were measured according to the methodology described in Claessen (1997). Penetration resistance was measured in the same samples, with moisture equilibrated at 6 $\mathrm{kPa}$ tension in a Richards apparatus, using a laboratory penetrometer equipped with a cone tip with diameter of $3.9 \mathrm{~mm}$, attack angle of $45^{\circ}$, and penetration velocity of $1 \mathrm{~mm} \mathrm{~s}^{-1}$. The value for each sample corresponds to the mean of the 30 values determined between 11 and $40 \mathrm{~mm}$ of depth of the soil core.

Total organic carbon was determined by wet sulphochromic oxidation, according to the methodology described in Tedesco et al. (1995), using two soil subsamples per plot collected near the rings used for soil physical analysis, and sampled in the layers of $0.00-0.05,0.05-0.10$ and $0.10-0.15 \mathrm{~m}$ of depth. The physical fractionation of organic carbon to separate the particulate fraction was performed according to Cambardella \& Elliott (1992) using $20 \mathrm{~g}$ of soil and $60 \mathrm{~mL}$ of sodium hexametaphosphate $\left(5 \mathrm{~g} \mathrm{~L}^{-1}\right)$ in a snap-cap flask. These samples were shaken for 16 hours in a horizontal shaker, and the suspension was passed through a $53 \mu \mathrm{m}$ screen. The material was oven-dried at $60^{\circ} \mathrm{C}$ and grinded, and organic carbon was determined according to the methodology described in Tedesco et al. (1995).

The grain yields of maize, common bean and soybean were estimated by harvesting the plants in the sampled plot, which was $12 \mathrm{~m}^{2}$ for maize and $5.4 \mathrm{~m}^{2}$ for common bean and soybean. The yield was expressed in $\mathrm{Mg} \mathrm{ha}^{-1}$ of cleaned grains with $13 \%$ moisture.

Data were submitted to analysis of variance and to the F test. Means were compared by the Tukey test, at 5\% probability, when significant effects of the treatments were observed, and, at $10 \%$ probability, when there was interaction between treatments and layers.

\section{Results and Discussions}

The treatment with winter intercropping (black oat + ryegrass + vetch) without grazing, i.e., intercropping cover, produced the greatest amount of dry biomass for soil cover in the two first years of the experiment (Table 1). In the third and fourth years, the treatment did not differ from fallow or oilseed radish. There was spontaneous emergence of ryegrass in the plots of the fallow treatment, which was maintained in the area as a cover plant. In three of the four years, oilseed 
radish showed low biomass production, mainly due to intensive frost. In a study performed in the same region, oilseed radish had a lower dry biomass production in comparison to black oat and to intercropping of winter cover crops species (Balbinot Junior et al., 2004).

Forage consumption in the pasture fertilized with $100 \mathrm{~kg} \mathrm{ha}^{-1}$ of $\mathrm{N}$ per year was approximately $30 \%$ higher than in the same pasture without $\mathrm{N}$ fertilization, during the four years of the experiment (Table 1). This suggests that $\mathrm{N}$ fertilization improved forage yield even in a soil with high soil organic matter content and with a legume species (vetch) in intercropping.

There were no differences among land use strategies during winter or among soil layers on microporosity and bulk density of soil, but macroporosity was lower in the surface layer in the pasture without $\mathrm{N}$ (Table 2). The reduction in macroporosity is related to the stress applied by animal trampling on the surface, which was greater than soil strength, resulting in plastic soil deformation (Horn \& Rostek, 2000). This is probably a consequence of the lower forage availability in the pasture without $\mathrm{N}$ treatment (Table 1), in which the animals trampled more to achieve the same amount of forage in comparison to the pasture with $\mathrm{N}$ treatment (Baggio et al., 2009). The increase in animal trampling in the same area results in additional soil compaction; the magnitude of this process depends not only on the soil strength and on the stress applied on the surface, but also on the frequency this stress is applied in the same area (Horn \& Rostek, 2000). The intensity of soil compaction may also be related to pasture availability

Table 1. Dry mass of residual straw on the soil from five land use strategies in winter, and forage dry mass consumption by cows in the annual winter pasture, with or without $100 \mathrm{~kg} \mathrm{ha}^{-1}$ of nitrogen $(\mathrm{N})$ fertilization per year, in four years of experiment ${ }^{(1)}$.

\begin{tabular}{lcccc}
\hline Treatment & 2006 & 2007 & 2008 & 2009 \\
\hline Intercropping cover & $4.97 \mathrm{a}$ & $4.37 \mathrm{a}$ & $4.26 \mathrm{a}$ & $4.15 \mathrm{a}$ \\
Pasture with N & $0.47 \mathrm{~b}$ & $0.71 \mathrm{~b}$ & $1.02 \mathrm{~b}$ & $0.89 \mathrm{~b}$ \\
Pasture without N & $0.49 \mathrm{~b}$ & $0.45 \mathrm{~b}$ & $1.14 \mathrm{~b}$ & $0.59 \mathrm{~b}$ \\
Oilseed radish & $0.77 \mathrm{~b}$ & $2.00 \mathrm{~b}$ & $4.69 \mathrm{a}$ & $2.96 \mathrm{a}$ \\
Fallow & $1.69 \mathrm{~b}$ & $1.67 \mathrm{~b}$ & $3.55 \mathrm{a}$ & $1.74 \mathrm{ab}$ \\
\hline $\mathrm{CV}(\%)$ & 29.9 & 30.8 & 31.3 & 37.7 \\
\hline \multicolumn{5}{c}{ Forage dry mass $\left(\mathrm{Mg} \mathrm{ha}^{-1}\right)$} \\
Pasture with N & 4.31 & 4.69 & 5.23 \\
Pasture without N & 3.50 & 3.64 & 3.78 & 2.54 \\
(1) Means followed by equal letters, in the columns, do not differ by the \\
Tukey test, at $5 \%$ probability.
\end{tabular}

due to stress attenuation by the pasture biomass, which is directly proportional to the amount of biomass on the soil surface (Braida et al., 2006).

Regarding resistance to penetration, significant differences among treatments and layers were observed. Among treatments, the differences were observed in the layers of $0.00-0.05$ and $0.05-0.10 \mathrm{~m}$ (Table 2). In the surface layer, a greater resistance to penetration in the grazed treatments was observed, which is related to macroporosity reduction in the pasture without $\mathrm{N}$. In the layer of $0.05-0.10 \mathrm{~m}$ only the pasture with $\mathrm{N}$ differed from oilseed radish, with the greatest and the lowest values, respectively.

In general, soil physical properties showed few differences between treatments and did not reach

Table 2. Soil physical properties in five land use strategies in winter and four soil layers, after four years of experiment ${ }^{(1)}$.

\begin{tabular}{|c|c|c|c|c|}
\hline \multirow[t]{2}{*}{ Treatment } & $0.00-0.05 \mathrm{~m}$ & $.05-0.10 \mathrm{~m}$ & $10-0.15 \mathrm{~m}$ & $0.15-0.20 \mathrm{~m}$ \\
\hline & \multicolumn{4}{|c|}{ Microporosity $\left(\mathrm{m}^{3} \mathrm{~m}^{-3}\right)$} \\
\hline Intercropping cover & $0.47 \mathrm{aA}$ & $0.47 \mathrm{aA}$ & $0.48 \mathrm{aA}$ & $0.47 \mathrm{aA}$ \\
\hline Pasture with $\mathrm{N}$ & $0.44 \mathrm{aA}$ & $0.46 \mathrm{aA}$ & $0.45 \mathrm{aA}$ & $0.46 \mathrm{aA}$ \\
\hline Pasture without $\mathrm{N}$ & $0.52 \mathrm{aA}$ & $0.48 \mathrm{aA}$ & $0.33 \mathrm{aA}$ & $0.47 \mathrm{aA}$ \\
\hline Oilseed radish & $0.45 \mathrm{aA}$ & $0.45 \mathrm{aA}$ & $0.46 \mathrm{aA}$ & $0.45 \mathrm{aA}$ \\
\hline Fallow & $0.46 \mathrm{aA}$ & $0.47 \mathrm{aA}$ & $0.46 \mathrm{aA}$ & $0.47 \mathrm{aA}$ \\
\hline Plot CV (\%) & \multicolumn{4}{|c|}{13.6} \\
\hline \multirow[t]{2}{*}{ Subplot CV (\%) } & \multicolumn{4}{|c|}{16.4} \\
\hline & \multicolumn{4}{|c|}{ Macroporosity $\left(\mathrm{m}^{3} \mathrm{~m}^{-3}\right)$} \\
\hline Intercropping cover & $0.15 \mathrm{aA}$ & $0.12 \mathrm{aA}$ & $0.12 \mathrm{aA}$ & $0.13 \mathrm{aA}$ \\
\hline Pasture with N & $0.10 \mathrm{abA}$ & $0.13 \mathrm{aA}$ & $0.13 \mathrm{aA}$ & $0.12 \mathrm{aA}$ \\
\hline Pasture without $\mathrm{N}$ & $0.06 \mathrm{bB}$ & $0.09 \mathrm{aAB}$ & $0.14 \mathrm{aA}$ & $0.12 \mathrm{aA}$ \\
\hline Oilseed radish & $0.16 \mathrm{aA}$ & $0.13 \mathrm{aA}$ & $0.12 \mathrm{aA}$ & $0.13 \mathrm{aA}$ \\
\hline Fallow & $0.14 \mathrm{aA}$ & $0.12 \mathrm{aA}$ & $0.12 \mathrm{aA}$ & $0.13 \mathrm{aA}$ \\
\hline Plot CV (\%) & \multicolumn{4}{|c|}{22.0} \\
\hline \multirow[t]{2}{*}{ Subplot CV (\%) } & \multicolumn{4}{|c|}{21.6} \\
\hline & \multicolumn{4}{|c|}{ Soil bulk density $\left(\mathrm{g} \mathrm{cm}^{-3}\right)$} \\
\hline Intercropping cover & $0.99 \mathrm{aA}$ & $1.07 \mathrm{aA}$ & $1.02 \mathrm{aA}$ & $0.98 \mathrm{aA}$ \\
\hline Pasture with $\mathrm{N}$ & $1.11 \mathrm{aA}$ & $1.06 \mathrm{aA}$ & $1.03 \mathrm{aA}$ & $1.01 \mathrm{aA}$ \\
\hline Pasture without $\mathrm{N}$ & $1.12 \mathrm{aA}$ & $1.04 \mathrm{aA}$ & $1.10 \mathrm{aA}$ & $0.99 \mathrm{aA}$ \\
\hline Oilseed radish & $0.97 \mathrm{aA}$ & $1.04 \mathrm{aA}$ & $1.02 \mathrm{aA}$ & $1.00 \mathrm{aA}$ \\
\hline Fallow & $1.00 \mathrm{aA}$ & $1.07 \mathrm{aA}$ & $1.04 \mathrm{aA}$ & $0.99 \mathrm{aA}$ \\
\hline Plot CV (\%) & \multicolumn{4}{|c|}{5.9} \\
\hline \multirow[t]{2}{*}{ Subplot CV (\%) } & \multicolumn{4}{|c|}{7.6} \\
\hline & \multicolumn{4}{|c|}{ Resistance to penetration (MPa) } \\
\hline Intercropping cover & $1.00 \mathrm{bA}$ & $1.11 \mathrm{abA}$ & $1.37 \mathrm{aA}$ & $1.20 \mathrm{aA}$ \\
\hline Pasture with N & $1.84 \mathrm{aA}$ & $1.57 \mathrm{aA}$ & $1.63 \mathrm{aA}$ & $1.43 \mathrm{aA}$ \\
\hline Pasture without $\mathrm{N}$ & $1.78 \mathrm{aA}$ & $1.20 \mathrm{abA}$ & $1.30 \mathrm{aA}$ & $1.55 \mathrm{aA}$ \\
\hline Oilseed radish & $1.05 \mathrm{bBC}$ & $0.81 \mathrm{bC}$ & $1.52 \mathrm{aAB}$ & $1.68 \mathrm{aA}$ \\
\hline Fallow & $1.09 \mathrm{bA}$ & $1.22 \mathrm{abA}$ & $1.27 \mathrm{aA}$ & $1.19 \mathrm{aA}$ \\
\hline Plot CV (\%) & \multicolumn{4}{|c|}{40.5} \\
\hline Subplot CV (\%) & \multicolumn{4}{|c|}{20.6} \\
\hline
\end{tabular}


values that could significantly reduce root development of the summer crops cultivated in succession, which was estimated in $2 \mathrm{MPa}$, for resistance to penetrartion (Arshad et al., 1996). The layer affected by animal trampling can be chiseled with the small chisel used in the crop planter, allowing root growth below this layer, in which no physical alteration was observed due to trampling and machinery traffic. These results can be explained by the stress distribution in the soil, since stress transmission in depth is directly related to the area in which it is applied on the surface and inversely related to soil strength (Sohne, 1958). Since cattle foot diameter is around $0.10 \mathrm{~m}$, trampling effect on soil physical properties below $0.10 \mathrm{~m}$ of depth is not expected. Soil compaction by trampling in the layer of $0.00-0.05$ increased soil penetration resistance, consequently attenuating part of the stress in this layer and avoiding downwards stress transmission (Horn \& Rostek, 2000).

The results of total and particulate organic carbon showed interactions among treatments and layers. Intercropping cover had greater total and particulate organic carbon in comparison to oilseed radish and fallow treatments in the layer of $0.00-0.05 \mathrm{~m}$ (Table 3 ), which is related to the amount of dry biomass added by each cropping system (Table 1). Total and particulate organic carbon were greater in the superficial layer

Table 3. Total and particulate organic carbon in five land use strategies in winter and three soil layers, after four years of experiment $^{(1)}$.

\begin{tabular}{|c|c|c|c|}
\hline Treatment & $0.00-0.05 \mathrm{~m}$ & $0.05-0.10 \mathrm{~m}$ & $0.10-0.15 \mathrm{~m}$ \\
\hline & \multicolumn{3}{|c|}{ Total organic carbon $\left(\mathrm{g} \mathrm{kg}^{-1}\right)$} \\
\hline Intercropping cover & $57.96 \mathrm{aA}$ & $43.15 \mathrm{aB}$ & $39.48 \mathrm{aB}$ \\
\hline Pasture with $\mathrm{N}$ & $52.08 \mathrm{abA}$ & $44.42 \mathrm{aB}$ & $42.26 \mathrm{aB}$ \\
\hline Pasture without N & $51.17 \mathrm{bA}$ & $40.38 \mathrm{aB}$ & $36.03 \mathrm{aB}$ \\
\hline Oilseed radish & $50.76 \mathrm{bA}$ & $40.92 \mathrm{aB}$ & $40.50 \mathrm{aB}$ \\
\hline Fallow & $48.82 \mathrm{bA}$ & $39.93 \mathrm{aB}$ & $39.53 \mathrm{aB}$ \\
\hline Plot CV (\%) & & 6.28 & \\
\hline \multirow[t]{2}{*}{ Subplot CV (\%) } & & 6.09 & \\
\hline & \multicolumn{3}{|c|}{ Particulate organic carbon $\left(\mathrm{g} \mathrm{kg}^{-1}\right)$} \\
\hline Intercropping cover & $98.52 \mathrm{aA}$ & $52.37 \mathrm{aB}$ & $40.83 \mathrm{aC}$ \\
\hline Pasture with $\mathrm{N}$ & $85.25 \mathrm{bA}$ & $49.08 \mathrm{aB}$ & $37.00 \mathrm{aC}$ \\
\hline Pasture without N & $91.63 \mathrm{abA}$ & $44.55 \mathrm{aB}$ & $36.12 \mathrm{aB}$ \\
\hline Oil seed radish & $84.91 \mathrm{bA}$ & $50.35 \mathrm{aB}$ & $41.63 \mathrm{aB}$ \\
\hline Fallow & $80.02 \mathrm{bA}$ & $43.50 \mathrm{aB}$ & $39.87 \mathrm{aB}$ \\
\hline Plot CV (\%) & & 13.53 & \\
\hline Subplot CV (\%) & & 8.27 & \\
\hline
\end{tabular}

in comparison to the two layers sampled below, due to straw accumulation on the surface in the no-tillage system, with minimal soil disturbance. Total and particulate organic carbon have been used as indicators of the effects related to biomass source and amounts on soil organic matter dynamics in cropping systems (Bayer et al., 2009). Intercropping systems improved soil organic matter content, which, over time, can improve crop production due to the better soil quality (Sainju et al., 2008).

In the four years of the experiment, land use in winter did not affect the grain yields of maize, common bean and soybean (Table 4). These results confirm that the use of annual winter pasture under grazing in the no-tillage system did not affect negatively soil physical properties related to soil compaction and, consequently, did not affect the grain yields of the crops cultivated in succession. The greater amount of straw in the intercropping cover treatment (Table 1), as well as the greater total and particulate organic matter content in the superficial layer (Table 3), did not result in greater grain yield over the years. However, these results may differ in other environmental conditions, especially in areas with high organic carbon oxidation.

Several studies have shown the possibility of land use in winter with annual pastures to produce cattle meat or milk, without negative impact on summer grain yield sown in succession. Assmann et al. (2003) observed that the grazing of white oat and ryegrass did not affect the grain yield of maize cultivated in succession in a no-tillage system. According to Nicoloso et al. (2006), there is a reduction in maize yield only when the crop is sown in succession to winter pasture, which is submitted to high intensity grazing. Lunardi et al. (2008) observed that the grazing of ryegrass in a crop-livestock system increased soybean yield in comparison to the treatment without grazing. Thus, the use of agricultural land with

Table 4. Grain yield $\left(\mathrm{Mg} \mathrm{ha}^{-1}\right)$ of the summer crops cultivated in succession with five land use strategies in winter, in four years of experiment.

\begin{tabular}{lcccc}
\hline Treatment & $\begin{array}{c}\text { Maize } \\
\text { 2006/2007 }\end{array}$ & $\begin{array}{c}\text { Common bean } \\
\text { 2007/2008 }\end{array}$ & $\begin{array}{c}\text { Soybean } \\
\text { 2008/2009 }\end{array}$ & $\begin{array}{c}\text { Maize } \\
\text { 2009/2010 }\end{array}$ \\
\hline Intercropping cover & 11.34 & 3.12 & 2.68 & 8.71 \\
Pasture with N & 11.05 & 3.11 & 2.54 & 8.94 \\
Pasture without N & 10.90 & 3.41 & 2.51 & 8.36 \\
Oilseed radish & 11.80 & 2.95 & 2.67 & 8.33 \\
Fallow & 11.37 & 2.98 & 2.48 & 8.57 \\
\hline CV (\%) & 8.0 & 13.3 & 9.4 & 6.3 \\
\hline
\end{tabular}


annual pasture in winter and crops for grain production in summer in a crop-livestock system is important to optimize the use of resources, which can improve the income per area and reduce the need to open new agricultural areas.

There was no difference in the grain yield of maize, common bean and soybean in the pasture with $\mathrm{N}$ fertilization during winter (Table 4). For maize, this was probably a result of nitrogen being supplied by biological $\mathrm{N}$ fixation by vetch in the intercropping system, which can become available for crops after the decomposition of the legume biomass. In common bean, and especially soybean, biological $\mathrm{N}$ fixation occurs in the crop itself, reducing the crops response to $\mathrm{N}$ fertilization.

\section{Conclusions}

1. The use of agricultural land, with a intercropping cover system in winter, results in greater straw addition and accumulation of total and particulate soil organic carbon on the soil surface layer, in comparison to the same intercropping system with grazing and land use with oilseed radish or fallow.

2. Annual winter pasture with crop-livestock system, cover crops, and fallow do not affect soil physical properties related to soil compaction, and have no effect on the grain yield of maize, common bean and soybean cultivated in succession.

\section{Acknowledgments}

To the farmer, Mr. Ivo Grein, for providing the area to install the experiment and other conditions to conduct the study; and to Fundação de Apoio à Pesquisa Científica e Tecnológica do Estado de Santa Catarina, for partial financial support.

\section{References}

ABREU, S.L.; REICHERT, J.M.; REINERT, D.J. Escarificação mecânica e biológica para a redução da compactação em Argissolo franco-arenoso sob plantio direto. Revista Brasileira de Ciência do Solo, v.28, p.519-531, 2004.

ARSHAD, M.A.; LOWERY, B.; GROSSMAN, R. Physical test for monitoring soil quality. In: DORAN, J.W.; JONES, A.J. (Ed.). Methods for assessing soil quality. Madison: Soil Science Society of America, 1996. p.123-141. (SSSA. Special publication, 49).

ASSMANN, T.S.; RONZELLI JUNIOR, P.; MORAES, A.; ASSMANN, A.L.; KOEHLER, H.S.; SANDINI, I. Rendimento de milho em área de integração lavoura-pecuária sob o sistema plantio direto, em presença e ausência de trevo branco, pastejo e nitrogênio. Revista Brasileira de Ciência do Solo, v.27, p.675-683, 2003.

BAGgio, C.; CARVAlHO, P.C. de F.; SILVA, J.L. da S; ANGHINONI, I.; LOPES, M.L.T.; THUROW, J.M. Padrões de deslocamento e captura de forragem por novilhos em pastagem de azevém-anual e aveia-preta manejada sob diferentes alturas em sistemas de integração lavoura-pecuária. Revista Brasileira de Zootecnia, v.38, p.215-222, 2009.

BALBINOT JUNIOR, A.A.; BACKES, R.L.; TÔRRES, A.N.L. Desempenho de plantas invernais na produção de massa e cobertura do solo sob cultivos isolado e em consórcios. Revista de Ciências Agroveterinárias, v.3, p.38-42, 2004.

BALBINOT JUNIOR, A.A.; MORAES, A. de; VEIGA, M. da; PELISSARI, A.; DIECKOW, J. Integração lavoura-pecuária: intensificação de uso de áreas agrícolas. Ciência Rural, v.39, p.1925-1933, 2009.

BAYER, C.; DIECKOW, J.; AMADO, T.J.C.; ELTZ, F.L.F.; VIEIRA, F.C.B. Cover crop effects increasing carbon storage in a subtropical no-till sandy Acrisol. Communications in Soil Science and Plant Analysis, v.40, p.1499-1511, 2009.

BRAIDA, J.A.; REICHERT, J.M.; VEIGA, M. da; REINERT, D.J. Resíduos vegetais na superfície e carbono orgânico do solo e suas relações com a densidade máxima obtida no ensaio proctor. Revista Brasileira de Ciência do Solo, v.30, p.605-614, 2006.

BRUM, A.L.; LEMES, C. da L.; SILVA, C.V.K. da; MULLER, P.K. A competitividade do trigo brasileiro diante da concorrência argentina. O comércio internacional e a competitividade pelo custo de produção. Revista Galega de Economia, v.14, p.1-15, 2005.

CAMBARDELlA, C.A.; ELLIOTT, E.T. Particulate soil organic-matter changes across a grassland cultivation sequence. Soil Science Society of America Journal, v.56, p.777-783, 1992.

CLAESSEN, M.E.C. (Org.). Manual de métodos de análise de solo. 2.ed. rev. atual. Rio de Janeiro: Embrapa-CNPS, 1997. 212p. (Embrapa-CNPS. Documentos, 1)

DIEKOW, J.; MIELNICZUK, J.; KNICKER, H.; BAYER, C.; DICK, D.P.; KÖGEL-KNABNER, I. Soil C and N stocks as affected by cropping systems and nitrogen fertilization in a southern Brazil Acrisol managed under no-tillage for 17 years. Soil and Tillage Research, v.81, p.87-95, 2005.

FONTANELI, R.S.; AMBROSI, I.; SANTOS, H.P. dos; IGNACZAK, J.C.; ZOLDAN, S.M. Análise econômica de sistemas de produção de grãos com pastagens anuais de inverno, em sistema de plantio direto. Pesquisa Agropecuária Brasileira, v.35, p.2129-2137, 2000.

GIACOMINI, S.J.; AITA, C.; VENDRUSCOLO, E.R.O. Matéria seca, relação $\mathrm{C} / \mathrm{N}$ e acúmulo de nitrogênio, fósforo e potássio em misturas de plantas de cobertura de solo. Revista Brasileira de Ciência do Solo, v.27, p.325-334, 2003.

HORN, R.; ROSTEK, J. Subsoil compaction processes: state of knowledge. In: HORN, R.; AKKER, J.J.H. van der; ARVIDSSON, J. (Ed.). Subsoil compaction: distribution, processes and consequences. Kiel: Christian Albrechts University, 2000. p.44-54. (Advances in Geoecology, 32). 
LUNARDI, R.; CARVALHO, P.C. de F; TREIN, C.R.; COSTA, J.A.; CAUDURO, G.F.; BARBOSA, C.M.P.; AGUINAGA, A.A.Q. Rendimento de soja em sistema de integração lavoura-pecuária: efeito de métodos e intensidade de pastejo. Ciência Rural, v.38, p.795-801, 2008.

NICOLOSO, R.S.; LANZANOVA, M.E.; LOVATO, T. Manejo das pastagens de inverno e potencial produtivo de sistemas de integração lavoura-pecuária no Estado do Rio Grande do Sul. Ciência Rural, v.36, p.1799-1805, 2006.

PANDOLFO, C.; BRAGA, H.J.; SILVA JÚNIOR, V.P.; MASSIGNAM, A.M.; PEREIRA, E.S.; THOMÉ, V.M.R. Atlas climático digital do Estado de Santa Catarina. Florianópolis: Epagri, 2002. 1 CD ROM.

SAINJU, U.M.; SENWO, Z.N.; NYAKATAWA, E.Z.; TAZISONG, I.A.; REDDY, K.C. Tillage, cropping systems, and nitrogen fertilizer source effects on soil carbon sequestration and fractions. Journal of Environmental Quality, v.37, p.880-888, 2008.
SOHNE, W. Fundamentals of pressure distribution and soil compaction under tractor tires. Agricultural Engineering, v.39, p.276-280, 1958.

SOLOS do Estado de Santa Catarina. Rio de Janeiro: Embrapa Solos, 2004. 726p. (Embrapa Solos. Boletim de pesquisa e desenvolvimento, 46).

SPERA, S.T.; SANTOS, H.P.; FONTANELI, R.S.; TOMM, G.O. Efeitos de sistemas de produção de grãos envolvendo pastagens sob plantio direto nos atributos físicos de solo e na produtividade. Revista Brasileira de Ciência do Solo, v.28, p.533-542, 2004.

TEDESCO, M.J.; GIANELLO, C.; BISSANI, C.A.; BOHNEN, H.; VOLKWEISS, S.J. Análises de solo, plantas e outros materiais. 2.ed. rev. Porto Alegre: Universidade Federal do Rio Grande do Sul, 1995. 174p. (UFRGS. Boletim técnico, 5).

TREIN, C.R.; COGO, N.P.; LEVIEN, R. Métodos de preparo do solo na cultura do milho e ressemeadura do trevo na rotação aveia+trevo/milho, após pastejo intensivo. Revista Brasileira de Ciência do Solo, v.15, p.105-111, 1991.

Received on June 30, 2010 and accepted on September 22, 2011 